\title{
Association between HLA-DRB1*04 and Malay patients with Vogt- Koyanagi-Harada syndrome in Malaysia: A case-control study
}

Alvernia M Samy ${ }^{1,2}$, Safinaz Mohd Khialdin², Nazila Ahmad Azli $^{1}$, Noor Hamidah Hussin $^{3}$, Azrena Anee ${ }^{3}$, Nor Fariza Ngah ${ }^{1,4}$

${ }^{1}$ Department of Ophthalmology, Hospital Selayang, Selangor, Malaysia; ${ }^{2}$ Department of Ophthalmology, Faculty of Medicine, The National University of Malaysia Medical Centre, Kuala Lumpur, Malaysia; ${ }^{3}$ Department of Diagnostic Laboratory Services, Hematology Unit, The National University of Malaysia Medical Centre, Kuala Lumpur, Malaysia; ${ }^{4}$ Department of Ophthalmology, Hospital Shah Alam, Selangor, Malaysia

\section{Abstract}

Introduction: Vogt-Koyanagi-Harada (VKH) is an autoimmune disorder affecting melanocyte-containing tissues. Major histocompatibility complex, class II, DR beta $1(H L A-D R B 1)^{\star} 04$ and its suballele $H L A-D R B 1^{\star} 0405$ were found to be associated with VKH in many studies.

Purpose: To determine the association of $H L A-D R B 1^{\star} 04$ and its suballele $H L A$ $D R B 1^{\star} 0405$ with VKH patients of Malay descent.

Materials and methods: A case control study was conducted among VKH patients of Malay ethnicity attending Ophthalmology Clinic, Hospital Selayang, Malaysia from December 2016 to December 2017. HLA-DRB1*04 allele-specific typing was performed on 14 Malay patients with VKH and 14 healthy controls using the polymerase chain reaction sequence-specific primer method. The data was then analysed using Fisher's Exact test.

Results: The frequency of $H L A-D R B 1^{\star} 04$ was noted to be higher in patients (42.9\%) compared to controls $(14.3 \%)$, but was not statistically significant $(p=0.209)$. The

Correspondence: 1 . Safinaz Mohd Khialdin, The National University of Malaysia Medical Centre, Jalan Yaacob Latif, Bandar Tun Razak, 56000 Kuala Lumpur, Malaysia.

E-mail: drsafinaz_1978@yahoo.com.my;

2. Nor Fariza Ngah, Hospital Shah Alam, Persiaran Kayangan, Seksyen 7, 40000 Shah Alam, Selangor, Malaysia.

E-mail: drfarizangah@gmail.com 
frequency of suballele HLA-DRB1*0405 was also increased in patients (42.9\%) vs controls (7.1\%); however, the results were not significant $(p=0.077)$.

Conclusion: In conclusion, although the findings were not statistically significant, the increased frequency of both HLA-DRB1*04 and its suballele HLA-DRB1*0405 may suggest a possible cause for the development of VKH among Malay patients.

Keywords: HLA-DRB1*04, HLA-DRB1*0405, Malay, Malaysia, Vogt-Koyanagi-Harada

\section{Hubungkait di antara HLA-DRB1 ${ }^{\star} 04$ dan pesakit Melayu dengan sindrom Vogt-Koyanagi-Harada di Malaysia: Kajian kawalan-kes}

\section{Abstrak}

Pengenalan: Vogt-Koyanagi-Harada (VKH) adalah gangguan autoimun yang mempengaruhi tisu yang mengandungi sel melanosit. Kompleks histokompatibiliti utama, kelas II, DR beta $1(H L A-D R B 1)^{\star} 04$ dan subalel $H L A-D R B 1^{\star} 0405$ didapati dikaitkan dengan VKH dalam banyak kajian banyak kajian terdahulu.

Tujuan: Bagi menentukan menentukan hubungkait $H L A-D R B 1^{*} 04$ dan subalelnya $H L A-D R B 1^{*} 0405$ dengan pesakit VKH berketurunan Melayu.

Bahan dan kaedah: Kajian kawalan kes dijalankan di kalangan pesakit VKH etnik Melayu yang menghadiri Klinik Oftalmologi, Hospital Selayang, Malaysia dari Disember 2016 hingga Disember 2017. HLA-DRB1 ${ }^{\star} 04$ jenis khusus alel dilakukan pada 14 pesakit Melayu dengan VKH dan 14 subjek kawalan yang sihat menggunakan kaedah primer turutan pra-tindak balas rantai polimerase. Data tersebut kemudian dianalisis menggunakan ujian Fisher's Exact.

Keputusan: Kekerapan $H L A-D R B 1^{*} 04$ diperhatikan lebih tinggi pada pesakit (42.9\%) berbanding dengan subjek kawalan (14.3\%), tetapi tidak signifikan secara statistik $(\mathrm{p}=0.209)$. Kekerapan subalel $H L A-D R B 1^{\star} 0405$ juga meningkat pada pesakit (42.9\%) vs subjek kawalan (7.1\%); Walau bagaimanapun, hasilnya tidak signifikan $(\mathrm{p}=0.077)$.

Kesimpulannya: Walaupun penemuan itu tidak signifikan secara statistik, peningkatan frekuensi $H L A-D R B 1^{*} 04$ dan subalel $H L A-D R B 1^{\star} 0405$ yang ditunjukkan ada kemungkinan menjadi penyebab VKH di kalangan pesakit Melayu.

Kata kunci: $H L A-D R B 1^{*} 04, H L A-D R B 1^{*} 0405$, Bangsa Melayu, Malaysia, VogtKoyanagi-Harada 


\section{Introduction}

Vogt-Koyanagi-Harada (VKH) syndrome is a multisystem, autoimmune disorder, which affects melanin-containing cells in the uveal tract, skin, meninges, and inner ear. ${ }^{1,2}$ Racial groups that are darkly pigmented, such as Asians, Hispanics, Native Americans, and Indians, are more frequently affected. The disease is more common in women and disease onset usually occurs from 20 to 50 years old. VKH is most prevalent in Japan, where $6.8-9.2 \%$ of uveitis cases are due to $\mathrm{VKH}^{1}{ }^{1}$ The prevalence of VKH in Singapore was found to be similar to the Japanese population. ${ }^{3}$

VKH is characteristically manifested as bilateral panuveitis. ${ }^{1,2}$ Posterior uveitis is a major cause of blindness worldwide (responsible for $10 \%$ of all cases of blindness). ${ }^{4}$ A census done at the Singapore National Eye Centre found VKH to be the commonest cause of panuveitis (32.8\%), which accounts for $7.2 \%$ of all uveitis cases that were treated from 1997-2001. ${ }^{3}$

VKH is associated with multifocal serous retinal detachment, signs of meningismus, and other extraocular manifestations, such as auditory derangement and integumentary changes. ${ }^{1,2}$ VKH syndrome has four stages or phases, which are the prodromal, uveitic, convalescent, and chronic recurrent phase. ${ }^{1}$ Ocular complications include glaucoma, cataract, subretinal fibrosis, and choroidal neovascularisation. ${ }^{1,2}$ Factors that contribute to poor prognosis are initial presence of ocular complications or severe presentation, multiple recurrences, inadequate treatment, and the presence of suballeles HLA-DRB1*0405 and $0410 .^{2}$

The diagnosis of VKH syndrome is usually made based on clinical findings. Ancillary tests can be helpful in certain situations to confirm the diagnosis or exclude other differential diagnoses. The tests include indocyanine green angiography, fluorescein angiography, optical coherence tomography, ocular ultrasound, and spinal tap to detect cerebrospinal fluid (CSF) lymphomonocytic pleocytosis. ${ }^{2,5}$ At present, there are no specific serological tests that are being used in the diagnosis of $\mathrm{VKH}^{1,2}$ Diagnostic criteria from the past have been replaced by the International Committee on Nomenclature Revised Diagnostic Criteria. ${ }^{5}$ In 2001, the first international workshop on VKH disease recommended new revised diagnostic criteria to help facilitate the diagnosis of VKH disease (Table 1). ${ }^{5}$ It includes both exclusion and inclusion criteria and classifies the disease into complete, incomplete, and probable according to the presenting clinical signs. ${ }^{5,6}$

The etiopathogenesis of VKH is still obscured, but selective, autoimmune processes against melanocytes have been hypothesised. ${ }^{1,7}$ The role of genetic factors may be vital in the development of VKH. In Japan, extensive studies have been conducted and it was found that $H L A-D R B 1^{*} 04$ had a significant association with VKH disease..$^{8-11}$ According to Islam et al., the suballele HLA-DRB1*0405 showed a significant association with VKH syndrome. ${ }^{8}$ The frequency of suballele HLA-DRB1*0405 was noted to be higher in chronic VKH patients. ${ }^{8,9} \mathrm{~A}$ meta-analysis by Shi et al. further confirmed that suballeles HLA-DRB1*0404, 0405, 0410 increased the risk of VKH. ${ }^{12}$ 
Table 1. Diagnostic criteria for VKH disease ${ }^{5}$

Complete VKH disease (criteria 1 to 5 must be present)

Incomplete VKH disease (criteria 1 to 3 and either 4 or 5 must be present)

Probable VKH (isolated ocular disease; criteria 1 to 3 must be present)

1. No history of penetrating ocular trauma or surgery preceding the initial onset of uveitis.

2. No clinical or laboratory evidence suggestive of other ocular disease entities.

3. Bilateral ocular involvement (a or b must be met, depending on the stage of disease when the patient is examined)

a. Early manifestations of disease

I. There must be evidence of a diffuse choroiditis (with or without anterior uveitis, vitreous inflammatory reaction, or optic disc hyperaemia), which may manifest as one of the following:

i. Focal areas of subretinal fluid, or

ii. Bullous serous retinal detachments.

II. With equivocal fundus findings; both of the following must be present as well:

i. Focal areas of delay in choroidal perfusion, multifocal areas of pinpoint leakage, large placoid areas of hyperfluorescence, pooling within subretinal fluid, and optic nerve staining (listed in order of sequential appearance) by fluorescein angiography and

ii. Diffuse choroidal thickening, without evidence of posterior scleritis by ultrasonography

b. Late manifestation of disease

I. History suggestive of prior presence of findings from 3a, and either both (II) and (III) below, or multiple signs from (III):

II. Ocular depigmentation (either of the following manifestation is sufficient):

i. Sunset glow fundus, or

ii. Sugiura sign

III. Other ocular signs:

i. Nummular chorioretinal depigmented scars, or

ii. Retinal pigment epithelium clumping and/or migration, or

iii. Recurrent or chronic anterior uveitis

4. Neurological/auditory findings (may have resolved by the time of examination)

a. Meningismus (malaise, fever, headache, nausea, abdominal pain, stiffness of the neck and back, or a combination of these factors; headache alone is not sufficient to meet definition of meningismus, however), or

b. Tinnitus, or

c. Cerebrospinal fluid pleocytosis

5. Integumentary finding (not preceding onset of central nervous system or ocular disease)
a. Alopecia, or
b. Poliosis, or
c. Vitiligo 
In Malaysia there has been no previous study on the genetic predisposition of patients with VKH disease. The human leucocyte antigen (HLA) association in VKH patients of Chinese and Indian descent has been previously studied in other countries. ${ }^{13,14}$ However, there were no similar studies done among Malay patients with VKH. Therefore, in this study, VKH patients of Malay ethnicity were analysed to determine the frequency and association with $H L A-D R B 1^{\star} 04$ and its suballele $H L A-D R B 1^{\star} 0405$. The relationship of suballeles HLA-DRB1* 0404 and 0410 were also explored. Further observation of the patients' clinical characteristics in terms of disease classification, recurrence, and ocular complications - such as glaucoma, cataract, subretinal fibrosis, and choroidal neovascularisation - in relation to $H L A-D R B 1^{\star} 04$ and its suballele $H L A-D R B 1^{\star} 0405$ were made.

\section{Materials and methods}

\section{Sample size}

A study by Islam et al. among the Japanese population noted the prevalence of $H L A-D R B 1^{*} 04$ was $93 \%$ among patients with VKH and $43.2 \%$ among controls. However, only suballele HLA-DRB1 ${ }^{\star} 0405$ showed a significant association with VKH syndrome $(77.2 \%)$ as compared to healthy controls $(26.2 \%) .{ }^{8}$ In view of the rarity of the disease, case-control study was chosen as the study design. Based on the research hypotheses, it is to be expected that VKH patients would have a higher rate of $H L A-D R B 1^{*} 0405$. Therefore, the sample size was calculated using PS power and sample size calculation software (version 3.0; Dupont and Plummer, 2009), based on a study of independent cases and controls with one control per case. Prior data indicated that the probability of exposure among controls was 0.262 . If the true probability of exposure among cases was 0.772 , then the study needed 14 case patients and 14 control patients to be able to reject the null hypothesis that the exposure rates for cases and controls are equal with probability (power) 0.8 . The type I error probability associated with this test of the null hypothesis is 0.05 .

\section{Subjects and data collection}

A case-control study was conducted from December 2016 to December 2017 among VKH patients attending the Ophthalmology Clinic, Hospital Selayang, Malaysia. Located close to the nation's capital of Kuala Lumpur, it is the referral centre for medical retina subspecialty in Malaysia. A total of 129 patients from all ethnicities were screened from the patient database in the clinic. There were 91 Malay patients with VKH and of these, 14 patients were randomly selected via an excel spreadsheet. Only Malay patients as defined by Article 160 of the Constitution of Malaysia and which could be traced back for at least two generations were eligible for this study. ${ }^{15}$

Patients were diagnosed by typical clinical presentation and according to the revised diagnostic criteria forVKH disease. ${ }^{5}$ Ancillary tests, such as optical coherence 
tomography, ocular ultrasound, fluorescein angiography, and indocyanine green angiography, were done in certain cases to aid in the diagnosis of VKH. Clinical data of patients, which included disease classification, chronic recurrence, and presence of ocular complications - such as glaucoma, cataract, subretinal fibrosis, and choroidal neovascularisation - were analysed. The course of uveitis was defined according to the Standardization of Uveitis Nomenclature. Chronic disease was characterised by persistent inflammation with relapse occurring less than three months after discontinuation of treatment. Recurrent uveitis was defined as recurring episodes of inflammation after being inactive without treatment for more than three months. ${ }^{16}$

Subjects that fulfilled the eligibility criteria were given a patient information sheet regarding the study prior to recruitment. An interview of the patients was conducted by the investigator using a standardized data extraction form. The form contained questions on demographic data and relevant clinical history. Written, informed consent was obtained prior to commencement of the study. For comparison, 14 randomly selected, unrelated, hospital-based, healthy controls with similar ethnic background, age, and sex-matched were included.

Subjects with any autoimmune disease or diseases that are related to the $H L A-D R B 1^{\star} 04$ gene were excluded. $H L A-D R B 1^{\star} 04$-related diseases include rheumatoid arthritis, ${ }^{17}$ multiple sclerosis, ${ }^{18}$ type 1 diabetes mellitus, ${ }^{19}$ lyme disease-induced arthritis, ${ }^{20}$ drug-triggered/idiopathic pemphigus vulgaris, ${ }^{21}$ pemphigoid gestationis, ${ }^{22}$ pemphigus foliaceus, ${ }^{23}$ obstructive hypertrophic cardiomyopathy, ${ }^{24}$ IgA nephropathy, ${ }^{25}$ polymyalgia rheumatica, ${ }^{26}$ alopecia areata, ${ }^{27}$ systemic lupus erythematosus, ${ }^{28}$ polycystic ovary syndrome, ${ }^{29}$ and autoimmune hepatitis. ${ }^{30}$ This research was approved by the Medical Research and Ethics Committees, Ministry of Health Malaysia, with National Medical Research Registry identification number NMRR-16-1075-29116 [Research ID: 29116]. This study was conducted in accordance with the tenets of the Declaration of Helsinki.

\section{DNA extraction}

Each of the subjects had $6 \mathrm{ml}$ of peripheral venous blood sample drawn and placed in a bottle containing ethylenediaminetetraacetic acid (EDTA). The collected samples were processed immediately for HLA typing and were not stored for future research. Genomic DNA was obtained from peripheral blood leukocytes using the commercial QIAamp DNA Blood Mini Kit (Qiagen, Hilden, Germany) from $200 \mu \mathrm{l}$ of buffy coat according to the manufacturer's instructions. $25-200 \mathrm{ng} / \mu \mathrm{l}$ final concentration of DNA is optimum for HLA typing with an A260/280 ratio of 1.65 to $1.80 .{ }^{31}$

\section{$H L A-D R B 1^{*} 04$ allele-specific typing by polymerase chain reaction sequence-specific primer (PCR-SSP)}

$H L A-D R B 1^{\star} 04$ allele-specific typing was done by PCR-SSP, a DNA-based tissue typing method. In contrast with other PCR-based methodologies, the SSP 
methodology utilised by One Lambda, Inc., Micro SSP ${ }^{\mathrm{TM}}$ DNA typing test, differentiates alleles in the PCR process. The Micro SSP ${ }^{\mathrm{TM}}$ DNA typing trays contain dried, preoptimized primers for PCR amplification of HLA alleles. Perfectly matched oligonucleotide primers are best for amplification of a target sequence by recombinant Taq polymerase. Amplification of target sequences (i.e., a positive result) occurs in precisely matched primer pairs, while there is no amplification in an unmatched primer pair (i.e., a negative result). Purified DNA samples, deoxynucleotide solution mix (Micro SSP ${ }^{\text {TM }}$ D-mix), and recombinant Taq polymerase were added to the preoptimized primer trays for PCR. The primer trays were placed in the thermal cycler using the recommended DNA cycling program. The amplified DNA fragments were then size-separated by $2.5 \%$ agarose gel electrophoresis. Visualisation was aided by ethidium bromide staining and ultraviolet light exposure. It was then documented via photography and interpreted accordingly. The results of PCR-SSP were interpreted based on whether particular PCR products were present or absent. ${ }^{32}$

\section{Statistical analysis}

Statistical analysis was performed using Statistical Package for Social Sciences (SPSS, version 20; IBM Corp., Armonk, NY, USA). Data was entered into a Microsoft excel worksheet (2013) and transferred to SPSS. Basic characteristics were analysed by descriptive statistics. Independent t-test was used to assess differences between patient and control age. Fisher's Exact test was used to test the association between two categorical variables, with a $p$-value $<0.05$ considered to be of statistical significance.

\section{Results}

A total of 14 Malay patients diagnosed with VKH were enrolled in this study, of whom $71.4 \%$ were female. Mean age for the patients was 38.9 years, with age ranging from 16 to 61 years old. Fourteen randomly selected, unrelated, healthy control subjects with no antecedent of VKH or any other autoimmune disease were included for comparison, and all individuals were of similar ethnic background, age, and sexmatched. There was no significant difference in age between patients and controls ( $p=0.735 ;$ Table 2).

The frequency of $H L A-D R B 1^{\star} 04$ was found to be increased in patients (42.9\%) as compared to controls (14.3\%); however, this was not statistically significant $(p=0.209)$. The frequency of suballele $H L A-D R B 1^{\star} 0405$ was also noted to be higher in patients $(42.9 \%)$ in comparison to controls (7.1\%), but did not reveal any significant association $\left(\mathrm{p}=0.077\right.$ ). Suballeles $H L A-D R B 1^{\star} 0404$ and $H L A-D R B 1^{\star} 0410$ were not detected in either group. Suballele $H L A-D R B 1^{\star} 0401$ was noted to be present only in controls (7.1\%; Table 3). 
Table 2. Patients and controls characteristics

\begin{tabular}{|l|l|l|l|l|}
\hline Variable & Value & $\begin{array}{l}\text { Patients } \\
(\mathbf{n = 1 4 )}\end{array}$ & $\begin{array}{l}\text { Controls } \\
(\mathbf{n = 1 4 )}\end{array}$ & p-valuea \\
\hline Gender & Male & $4(28.6 \%)$ & $4(28.6 \%)$ & \\
& Female & $10(71.4 \%)$ & $10(71.4 \%)$ & \\
\hline Age (years) & Mean, range & $38.9,16-61$ & $41,19-64$ & 0.735 \\
\hline
\end{tabular}

${ }^{a} \mathrm{p}$-values were calculated using the independent t-test.

Table 3. HLA-DRB1*04 allele and suballeles frequencies in VKH patients and controls

\begin{tabular}{|l|l|l|l|}
\hline Allele/ Suballele & Patients $(\mathbf{n}=\mathbf{1 4})$ & Controls $(\mathbf{n}=\mathbf{1 4})$ & $\mathbf{p}$-valuea \\
\hline HLA-DRB1*04 & $6(42.9 \%)$ & $2(14.3 \%)$ & 0.209 \\
\hline$H L A-D R B 1^{\star} 0405$ & $6(42.9 \%)$ & $1(7.1 \%)$ & 0.077 \\
\hline$H L A-D R B 1^{\star} 0404$ & $0(0.0 \%)$ & $0(0.0 \%)$ & - \\
\hline$H L A-D R B 1^{\star} 0410$ & $0(0.0 \%)$ & $0(0.0 \%)$ & - \\
\hline$H L A-D R B 1^{\star} 0401$ & $0(0.0 \%)$ & $1(7.1 \%)$ & - \\
\hline
\end{tabular}

HLA-DRB1: major histocompatibility complex, class II, DR beta 1 ; ${ }^{a} \mathrm{p}$-values were calculated using the Fisher's Exact test.

Table 4. Clinical features in $H L A-D R B 1^{\star} 0405$-positive and $H L A-D R B 1^{\star} 0405$-negative VKH patients

\begin{tabular}{|l|l|l|}
\hline \multirow{2}{*}{ Clinical features } & \multicolumn{2}{|c|}{ VKH patients } \\
\cline { 2 - 3 } & $\begin{array}{l}\text { HLA-DRB1*0405 } \\
\text { positive (n=6) }\end{array}$ & $\begin{array}{l}\text { HLA-DRB1*0405 } \\
\text { negative (n = 8) }\end{array}$ \\
\hline Complete VKH & $0(0)$ & $0(0)$ \\
Incomplete VKH & $4(66.7 \%)$ & $4(50.0 \%)$ \\
Probable VKH & $2(33.3 \%)$ & $4(50.0 \%)$ \\
\hline Chronic recurrence & $5(83.3 \%)$ & $4(50.0 \%)$ \\
\hline Ocular complications: & & \\
Cataract & $5(83.3 \%)$ & $6(75.0 \%)$ \\
Glaucoma & $2(33.3 \%)$ & $1(12.5 \%)$ \\
Subretinal fibrosis & $0(0.0 \%)$ & $0(0.0 \%)$ \\
Choroidal neovascularisation & $0(0.0 \%)$ & $0(0.0 \%)$ \\
\hline
\end{tabular}

HLA-DRB1: major histocompatibility complex, class II, DR beta 1. 
In VKH patients with $H L A-D R B 1^{\star} 0405$ positive, $66.7 \%$ had incomplete $\mathrm{VKH}$ and $33.3 \%$ had probable $\mathrm{VKH}$. In HLA-DRB1*0405-negative patients, the frequency of both incomplete and probable VKH was similar (50\%). There were no patients with complete VKH noted. The chronic recurrence rate for $\mathrm{VKH}$ patients that were positive for HLA-DRB1*0405 (83.3\%) was noted to be higher compared to patients that were negative for $H L A-D R B 1^{\star} 0405$ (50\%). The frequency of ocular complications, such as cataract and glaucoma, was higher in $H L A-D R B 1^{*} 0405$-positive patients - cataract (83.3\%), glaucoma (33.3\%) - vs HLA-DRB1*0405-negative patients: cataract (75\%), glaucoma (12.5\%; Table 4).

\section{Discussion}

VKH is a bilateral, granulomatous panuveitis involving melanocyte-containing tissues that is associated with extraocular manifestations. Although the specific cause of VKH syndrome has yet to be ascertained, the possible, suggested pathogenesis is an autoimmune response towards melanocytes in a genetically predisposed person. ${ }^{1,7}$ Viral symptoms that precede the onset of the disease could link viral infection as an inciting factor in this autoimmune process. ${ }^{2,7}$ Mechanisms that could explain this association are viral molecular mimicry and cross-reactions to melanocytes. Molecular studies utilizing PCR on CSF from patients with VKH revealed the presence of the Epstein-Barr virus. ${ }^{1}$ According to Sugita et al., T-cell cross-reactivity between tyrosinase and cytomegalovirus antigen could be involved in the onset of $\mathrm{VKH}$. The data was inconclusive, which requires further studies to identify the triggering factors. ${ }^{33}$

Electron microscope studies of VKH eyes revealed a direct contact between melanocytes and lymphocytes, followed by absence of choroidal melanocytes at the site of contact. ${ }^{1}$ Studies in active VKH eyes demonstrated increased activated T lymphocytes in the choroidal inflammatory foci that expressed both early and late T-cell activation markers. During the convalescent stage of VKH, presence of CD4+ and CD8+ cytotoxic T lymphocytes was noted, with lymphocyte infiltrates and loss of choroidal melanocytes. Immunohistochemical evidence has contributed further to the understanding of the autoimmune process in VKH disease. The suggested autoimmune mechanism involved is T-cell mediated, delayed-type hypersensitivity towards uveal melanocytes that abnormally express class II major histocompatibility complex (MHC) antigens. ${ }^{1,7}$ In humans, HLA class II is an MHC on chromosome 6p21 that encodes for specific cell-surface molecules on antigen-presenting cells. The CD4+ T-helper cell receptor then interacts with the exogenous antigen presented by HLA molecules, resulting in an immune response that leads to host-tissue destruction. ${ }^{34}$

Various studies have been conducted in other populations and VKH was noted to be associated with several HLA serotypes and genotypes. The linked HLA serotypes 
include: HLA-DQ4 in Japanese; ${ }^{8} H L A-D Q 7$ in Chinese; ${ }^{13} H L A-D R 1$ in Hispanic ${ }^{35} H L A-D R 4$ in Japanese, ${ }^{8}$ Chinese, ${ }^{13}$ Hispanic, ${ }^{35,36}$ and Italian; ${ }^{37}$ and HLA-DR53 in Japanese. ${ }^{8}$ The associated HLA genotypes include: $H L A-D Q A 1^{*} 0301$ in Japanese; ${ }^{8} H L A-D Q B 1^{\star} 0401$ in Japanese; ;,11 HLA-DRB1*0101 in Hispanic; ${ }^{36}$ HLA-DRB1*0404 in Hispanic; ${ }^{38}$ HLA$D R B 1^{\star} 0405$ in Japanese, $, 8,10,11$ Hispanic, ${ }^{38}$ Saudi Arabian, ${ }^{39}$ Brazilian, ${ }^{40}$ Korean, ${ }^{41}$ and Indian; ${ }^{14}$ and $H L A-D R B 1^{\star} 0410$ in Indian. ${ }^{14}$ Although multiple HLA serotypes and genotypes have been found to be associated with VKH, HLA-DRB1*04/DR4 and its suballele $H L A-D R B 1^{*} 0405$ in particular were reported in most populations. Therefore, in our study, high-resolution typing via PCR-SSP was limited to HLA-DRB1*04 alleles.

In our patients (42.9\%), the frequency of $H L A-D R B 1^{*} 04$ was higher compared to the control group (14.3\%), which suggests a possible association with VKH in our patients. All patients who had $H L A-D R B 1^{*} 04$ detected were positive for only suballele $H L A-D R B 1^{\star} 0405$, with patients $(42.9 \%)$ vs controls $(7.1 \% ; p=0.077)$. Although the results were not statistically significant, the association has been proven and well documented in other study populations. Islam et al. showed that the prevalence of $H L A-D R B 1^{*} 04$ was $93 \%$ among patients with VKH and $43.2 \%$ among controls, with a relative risk (RR) of $17.4 .^{8}$ It was noted that VKH patients that have the $H L A-D R B 1^{*} 04$ gene either carry suballele $H L A-D R B 1^{*} 0405$ or $0410,8,10,11$ However, by statistical analysis, only $H L A-D R B 1^{*} 0405$ showed a significant association with VKH syndrome (77.2\%) compared to healthy controls (26.2\%) with an RR of 9.5. ${ }^{8}$ Damico et al. reinforced the importance of this allele as a predisposition to the development of VKH syndrome. The study showed that there was an increased sensitivity in VKH patients to melanocyte epitopes, and patients with $H L A-D R B 1^{\star} 0405$ demonstrated a larger melanocyte-derived peptide repertoire. ${ }^{42}$

Shi et al. revealed a pooled odds ratio (OR) of 8.42 for the association of $H L A-D R B 1^{*} 04$ with $\mathrm{VKH}$. This meta-analysis confirmed the association of HLA-DR4/ $H L A-D R B 1^{*} 04$ with VKH. It also identified suballeles $H L A-D R B 1^{*} 0404,0405$, and 0410 as risk alleles for $\mathrm{VKH}$, and $H L A-D R B 1^{*} 0401$ as the protective allele. Genotyping of the suballeles $H L A-D R B 1^{\star} 0404,0405,0410$ and 0401 was suggested for patients with VKH. ${ }^{12}$ Among our study patients, both $H L A-D R B 1^{*} 0404$ and 0410 were absent, and $H L A-D R B 1^{\star} 0401$ was present only in control subjects (7.1\%). A systemic review and meta-analysis of 21 studies with $1853 \mathrm{VKH}$ patients showed a different strength of association between VKH and $H L A-D R B 1^{\star} 04$; the diversity was due to different ethnicity, with the highest association among Eastern Asians $(O R=13.69)$ and the lowest in Indians $(\mathrm{OR}=2.09) .{ }^{12}$ Different ethnic backgrounds with variable strengths of association could possibly explain the weak association with $H L A-D R B 1^{\star} 04$ among Malay patients.

The clinical course of VKH patients that are positive for $H L A-D R B 1^{\star} 0405$ was compared with patients negative for $H L A-D R B 1^{*} 0405$. The frequency of chronic recurrence was higher in $H L A-D R B 1^{*} 0405$-positive patients $(83.3 \%)$ than in $H L A-D R B 1^{\star} 0405$-negative patients (50\%). Similar findings were noted in a Japanese study, where the frequency of suballele HLA-DRB1*0405 was increased in chronic VKH 
patients (93\%) compared to nonchronic patients (56\%). ${ }^{8,9}$ The presence of ocular complications, such as cataract and glaucoma, was higher in patients positive for this suballele, with $83.3 \%$ and $33.3 \%$, respectively. Kim et al. revealed that patients with $H L A-D R B 1^{*} 0405$ have more ocular complications than $H L A-D R B 1^{*} 0405$-negative patients. ${ }^{41}$ Although the study subject numbers were not appropriate for statistical analysis, we surmised the possibility of a relation between HLA-DRB1*0405 and poorer disease outcome.

\section{Conclusion}

Although the association between $H L A-D R B 1^{*} 04$ and its suballele $H L A-D R B 1^{\star} 0405$ with VKH patients of Malay descent was found to be statistically insignificant, the increased frequency of this HLA allele gives us an insight into the possible etiopathogenesis of VKH syndrome among the Malay population. As this study is only an observation of a small cohort and not a representation of the Malaysian population, the novel pilot data could be of interest and importance for the direction of future studies.

\section{Acknowledgements}

We thank the Director General of Health, Ministry of Health Malaysia, for the permission to publish this study. Our sincere gratitude goes to Dr Zabri bin Kamarudin, the Head of Department, Ophthalmology, Hospital Selayang, for his guidance. We also express our gratitude to Assoc Prof Dr Jemaima Che Hamzah, the Head of Department, Ophthalmology, The National University of Malaysia Medical Centre, for her support. A special thanks to Dr Hjh Siti Zaleha bt Mohd Salleh, the Director, Hospital Selayang, for her advice and assistance and providing us with the necessary facilities to conduct our study. Our thanks to Dr Nor Asiah Muhamad, Institute for Public Health, for her advice during the preparation of this study. Appreciation is also due towards the National University of Malaysia Medical Centre for providing funding through the research grant number FF-2016-170. Lastly, we would like to thank everyone who has contributed to this study.

\section{References}

1. Moorthy RS, Inomata H, Rao NA. Vogt-Koyanagi-Harada syndrome. Surv Ophthalmol. 1995;39(4):265292.

2. Sakata VM, da Silva FT, Hirata CE, de Carvalho JF, Yamamoto JH. Diagnosis and classification of Vogt-Koyanagi-Harada disease. Autoimmun Rev. 2014;13(4-5):550-555. 
3. Chee SP, Jap A, Bacsal K. Spectrum of Vogt-Koyanagi-Harada disease in Singapore. Int Ophthalmol. 2007;27(2-3):137-142.

4. Suttorp-Schulten MS, Rothova A. The possible impact of uveitis in blindness: a literature survey. Br J Ophthalmol. 1996;80(9):844-848.

5. Read RW, Holland GN, Rao NA, et al. Revised diagnostic criteria for Vogt-Koyanagi-Harada disease: report of an international committee on nomenclature. Am J Ophthalmol. 2001;131(5):647-652.

6. Rao NA, Sukavatcharin S, Tsai JH. Vogt-Koyanagi-Harada disease diagnostic criteria. Int Ophthalmol. 2007;27(2-3):195-199.

7. Damico FM, Bezerra FT, Silva GC, Gasparin F, Yamamoto JH. New insights into Vogt-Koyanagi-Harada disease. Arq Bras Oftalmol. 2009;72(3):413-420.

8. Islam SM, Numaga J, Fujino Y, et al. HLA Class II genes in Vogt-Koyanagi-Harada disease. Invest Ophthalmol Vis Sci. 1994;35(11):3890-3896.

9. Islam SM, Numaga J, Matsuki K, Fujino Y, Maeda H, Masuda K. Influence of HLA-DRB1 gene variation on the clinical course of Vogt-Koyanagi-Harada disease. Invest Ophthalmol Vis Sci. 1994;35(2):752756.

10. Shindo Y, Inoko H, Yamamoto T, Ohno S. HLA-DRB1 typing of Vogt-Koyanagi-Harada's disease by PCR-RFLP and the strong association with DRB1*0405 and DRB1*0410. $\mathrm{Br} \mathrm{J}$ Ophthalmol. 1994;78(3):223-226.

11. Shindo Y, Ohno S, Yamamoto T, Nakamura S, Inoko H. Complete association of the HLA-DRB1*04 and -DQB1*04 alleles with Vogt-Koyanagi-Harada's disease. Hum Immunol. 1994;39(3):169-176.

12. Shi T, Lv W, Zhang L, Chen J, Chen H. Association of HLA-DR4/HLA-DRB1*04 with Vogt-Koyanagi-Harada disease: A systemic review and meta-analysis. Sci Rep. 2014;4:6887.

13. Zhang XY, Wang XM, Hu TS. Profiling human leukocyte antigen in Vogt-Koyanagi-Harada syndrome. Am J Ophthalmol. 1992;113(5):567-572.

14. Tiercy JM, Rathinam SR, Gex-Fabry M, Baglivo E. A shared HLA-DRB1 epitope in DR beta first domain is associated with Vogt-Koyanagi-Harada syndrome in Indian patients. Mol Vis. 2010;16:353-358.

15. Constitution of Malaysia (Reprint 2010). Federal Constitution. 1963 (Article 160).

16. Jabs DA, Nussenblatt RB, Rosenbaum JT. Standardization of uveitis nomenclature (SUN) working group. Standardization of uveitis nomenclature for reporting clinical data. Results of the first international workshop. Am J Ophthalmol. 2005;140(3):509-516.

17. Angelini G, Morozzi G, Delfino L, et al. Analysis of HLA DP, DQ, and DR alleles in adult Italian rheumatoid arthritis patients. Hum Immunol. 1992;34(2):135-141.

18. Laroni A, Calabrese M, Perini P, et al. Multiple sclerosis and autoimmune diseases: Epidemiology and HLA-DR association in North-east Italy. J Neurol. 2006;253(5):636-639.

19. Fernandez-Viña M, Ramirez L, Raskin P, Stastny P. Genes for insulin-dependent diabetes mellitus (IDDM) in the major histocompatibility complex (MHC) of African-Americans. Tissue Antigens. 1993;41(2):57-64.

20. Gross D, Forsthuber T, Tary-Lehmann M, et al. Identification of LFA-1 as a candidate autoantigen in treatment-resistant Lyme arthritis. Science. 1998;281(5377):703-706.

21. Matzner Y, Erlich H, Brautbar C, et al. Identical HLA class II alleles predispose to drug-triggered and idiopathic pemphigus vulgaris. Acta Derm Venereo. 1995;75(1):12-14. 
22. Shornick J, Jenkins R, Artlett C, et al. Class II MHC typing in pemphigoid gestationis. Clin Exp Dermatol. 1995;20(2):123-126.

23. Matsuyama M, Hashimoto K, Yamasaki Y, et al. HLA-DR antigens in pemphigus among Japanese. Tissue Antigens. 1981;17(2):238-239.

24. Sakurami T, Ueno Y, Iwaki Y, Park M, Terasaki P, Saji H. HLA-DR specificities among Japanese with several autoimmune diseases. Tissue Antigens. 1982;19(2):129-133.

25. Kashiwabara H, Shishido H, Tomura S, Tuchida H, Miyajima T. Strong association between IgA nephropathy and HLA-DR4 antigen. Kidney Int. 1982;22(4):377-382.

26. Cid MC, Ercilla G, Vilaseca J, et al. Polymyalgia rheumatica: a syndrome associated with HLA-DR4 antigen. Arthritis Rheum. 1988;31(5):678-682.

27. Entz P, Blaumeiser B, Betz RC, et al. Investigation of the HLA-DRB1 locus in alopecia areata. Eur J Dermatol. 2006;16(4):363-367.

28. Galeazzi M, Sebastiani G, Tincani A, et al. HLA class II alleles associations of anticardiolipin antibodies. Lupus. 2000;9(1):47-55.

29. Kaibe M, Takakuwa K, Murakawa H, Ishii K, Tamura M, Tanaka K. Studies on the human leukocyte antigens in patients with polycystic ovary syndrome in a Japanese population-possible susceptibility of HLA-A11 and -DRB1 0403 to patient population with polycystic ovary syndrome. Am J Reprod Immunol. 2006;55(4):301-306.

30. Vázquez-García M, Aláez C, Olivo A, et al. MHC class Il sequences of susceptibility and protection in Mexicans with autoimmune hepatitis. J Hepato. 1998;28(6):985-990.

31. DNA Mini and Blood Mini handbook. QIAGEN QIAamp ${ }^{\circledR}$.

32. Product insert, Micro SSP ${ }^{\mathrm{TM}}$ HLA DNA typing trays. One Lambda

33. Sugita S, Takase H, Imai Y, Mochizuki M. Immunopathogenic mechanisms of a melanocyte-specific autoimmune disease: a cross-reaction between tyrosinase peptides and cytomegalovirus antigen. Invest Ophthalmol Vis Sci. 2002; 43(13):1529.

34. Gough SC, Simmonds MJ. The HLA region and autoimmune disease: associations and mechanisms of action. Curr Genomics. 2007;8(7):453-465.

35. Weisz JM, Holland GN, Roer LN, et al. Association between Vogt-Koyanagi-Harada syndrome and HLA-DR1 and -DR4 in Hispanic patients living in southern California. Ophthalmology. 1995;102(7):1012-1015.

36. Alaez C, del Pilar Mora M, Arellanes L, et al. Strong association of HLA class II sequences in Mexicans with Vogt-Koyanagi-Harada's disease. Hum Immunol. 1999;60(9):875-882.

37. Pivetti-Pezzi P, Accorinti M, Colabelli-Gisoldi RA, Pirraglia MP. Vogt-Koyanagi-Harada disease and HLA type in Italian patients. Am J Ophthalmol. 1996;122(6):889-891.

38. Aláez C, Flores-A H, Concha del Río LE, et al. Major histocompatibility complex and strong human leukocyte antigen-DRB1 and gender association with Vogt-Koyanagi-Harada syndrome in Mexican Mestizos. Hum Immunol. 2011;72(12):1198-1203.

39. Iqniebi A, Gaafar A, Sheereen A, et al. HLA-DRB1 among patients with Vogt-Koyanagi-Harada disease in Saudi Arabia. Mol Vis. 2009;15:1876-1880.

40. Goldberg AC, Yamamoto JH, Chiarella JM, et al. HLA-DRB1*0405 is the predominant allele in Brazilian Patients with Vogt-Koyanagi-Harada disease. Hum Immunol. 1998;59(3):183-188. 
41. Kim MH, Seong MC, Kwak NH, et al. Association of HLA with Vogt-Koyanagi-Harada syndrome in Koreans. Am J Ophthalmol. 2000;129(2):173-177.

42. Damico FM, Cunha-Neto E, Goldberg AC, et al. T-cell recognition and cytokine profile induced by melanocyte epitopes in patients with HLA-DRB1*0405-positive and -negative Vogt-Koyanagi-Harada uveitis. Invest Ophthalmol Vis Sci. 2005;46(7):2465-2471. 